\title{
The Implementation of Islamic Education in Building Preprimary Disabled Students Character
}

\author{
Edi Sutejo ${ }^{1^{*}}$,Nurdin Nurdin ${ }^{2}$, and Ahmad Syahid ${ }^{3}$ \\ ${ }^{1}$ Islamic Education Department, Postgraduate, Institut Agama Islam Negeri Palu \\ 2 Islamic Education Department, Postgraduate, Institut Agama Islam Negeri Palu \\ ${ }^{3}$ Islamic Education Department, Postgraduate, Institut Agama Islam Negeri Palu
}

\section{ABSTRACT}

This study examined the implementation of Islamic education in building preprimary disabled students characters. The main focus of this study was teachers strategies in building characters for mentally retarded children in the subject of Islamic religious education and character. In conducting the study, we used a qualitative case study method. The case of this study was a state disabled in Palu city. Data were gathered through direct field observation, in-depth interviews which involve teachers and the school principla. We also analyzed written material, such as the school teaching activities, to understand how the character building strategies were integrated in the disabled school curriculum. Our study found that the teacher's strategies in building character of mentally retarded children in the subject of Islamic Religious Education were through habituation and modeling techniques. The teachers of Islamic religious education applied learning habits that contain good values and attitudes. This included familiarizing with habits to maintaining cleanliness, Quran recitation, practicing prayers, and getting used to giving donation
ARTICLE

INFORMATION

Keywords:

Islamic education, Islamic charaters, disabled students character, character building 


\section{Introduction}

Character education is considered very important, and this is not only in Indonesia but also throughout the world, both developing and developed countries. According to Ahmad Baso, "Imam al-Gazali himself wrote works in Persian that talked about character. politics, because the character is very important and in accordance with the mission of Islam, rahmatan lilalamin.". ${ }^{1}$ The importance of this character was reinforced by the Indonesian president Susilo Bambang Yudhoyono in his 2011 speech.

Character education is considered important because so many problems arise in the school environment or in the community, due to the lack of good character, especially among students. The school environment is very good for the character education of children. Character education is an extension of the family, meaning that school is an advanced place to lay the basis for the behaviour of children. ${ }^{2}$ Therefore, character education is important in the school environment because school is the second education after education in the family. ${ }^{3}$ The rise of a nation is

1 Ahmad Baso, Islam Nusantara, (Cet.1, Jakarta: Pusta Afid, 2015), 7.

2 Agung Amrih Gunawan dkk, Bimbingan Keterampilan Hidup Personal Bagi Anak Tunagrahita Ringan Di SLB Kota Bandung, Vol. 4 No. 1 (Januari 2017), 65, http://ejournal.utp.ac.id/index.php/JMSG/arti cle/view/484 (Diakses 14 Desember 2019).

3 Rusli, Rusli. (2020). The Role of Family in Preventing Social Conflict in Society From Islamic Perspectives. HUNAFA: Jurnal Studia Islamika, 17(1), 108-122. because the nation has good character, and the destruction of a nation is caused because the character of a nation is bad. As said by Syaaqi Bey, he said that "a people will be eternal and victorious, if morals are still there, the people will be destroyed and perish, if morals and character are gone".4

There are people who think that character is not to be taught, such as mathematics, physics, social science, and so on, but to be formed and instilled. Therefore, the learning strategy is directed at achieving Islamic Religious Education (PAI) and character. The purpose of education is not only in the cognitive domain but also in character and skills.

The teaching of Islamic Religious Education (PAI) and character in the school environment still have many obstacles, difficulties and mental and intellectual retardation. What is more, for mentally retarded students, because mentally retarded students have obstacles, difficulties and retardation in mental and intellectual development that are different from other normal students. Therefore, the selection of the right strategy in inculcating character must pay attention to each characteristic of developmentally disabled students. ${ }^{5}$

One example of the obstacle is the difficulty in absorbing Islamic Religious

\footnotetext{
4 Muhammad Amin, Membangun Pribadi Berbudi Pekerti, 2.

5 Askar, Askar, Adawiyah, Adawiyah, \& Nurdin, Nurdin. (2021). Understanding Students' Psychological Distress Complaints through Online Academic Advising Support. Medico Legal Update, 21(3), 162-167.
}

e-ISSN: 2715-4572

p-ISSN: 2716-1439 
Education (PAI) lessons and character, such as understanding good and bad behaviour, not being allowed to do evil or being ignorant to others, etc. Another obstacle is the lack of inadequate facilities and infrastructure, resulting in a lack of understanding of the meaning and benefits of the character, at the State Special School (SLB) 2 Palu, for example, there are some developmentally disabled students who have difficulty understanding Islamic Religious Education (PAI) lessons and character.

Based on observations made by researchers in the field, the reason the researchers took the title "teacher's strategy in inculcating character for developmentally disabled children in the subject of Islamic Religious Education (PAI) at the State Special School (SLB) 2 Palu "is that researchers see the difficulty of developmentally disabled children in understanding Character education is due to intellectual limitations, then inadequate facilities and infrastructure, and usual students at the State 2 Palu Special School (SLB) whose manners deviate from Islamic Religious Education (PAI), such as jail with friends, lack of good understanding and bad, often late for school and others, but Islamic Religious Education (PAI) and character teachers try to overcome these problems with certain strategies.

\section{Literature review}

\subsection{Definition of Character Education}

According to the Indonesian Dictionary, embedness is the process, method, act of planting, planting, or instilling". 6 Then the cultivation of character can also be interpreted as "a serious effort in the context of forming children",7 "Business is the values of human life that are truly implemented not because of a habit, but based on understanding and self-awareness to be good."8 From the above understandings, the cultivation of character is an effort, method, process, seriously to instil or form a child or someone.

The building of character is the same as talking about the purpose of education, because there are so many opinions of experts who say that the purpose of education is the cultivation of character. Muhammad Athiyah alAbrasyi, for example, said that Abuddin Nata quoted him as saying that "ethics education is the soul and purpose of Islamic education.", 9 and one of the missions sent by the Prophet Muhammad. to this world is to perfect human character. ${ }^{10}$ Similarly, Ahmad D. Marimba argues in Abuddin Nata that "the main goal of Islamic education is identical with the life goal of every Muslim, namely to become a servant of

\begin{tabular}{lrrr}
\hline & \multicolumn{2}{c}{${ }^{2}$ Ruslan } & \multicolumn{2}{c}{$\mathrm{dkk}^{2}$} & Penanaman \\
Nilai-nilai & Moral & Pada & Peserta didik \\
Di SD & Negeri & Lampeuneurut, Volume. \\
1, & Nomer. & 1, & $(2016), \quad 70$,
\end{tabular}

http://www.jim.unsyiah.ac.id/pgsd/article/vie w/431, (di akses 11 Januari 2020).

7 Abuddin Nata, Ahklak Tasawuf, (Jakarta: RajaGrafindo Persada, 2010), 158.

8 Nurul Zuriah, Pendidikan Moral dan Budi Pekerti dalam Perpektif Perubahan, (; Jakarta: PT. Bumi Aksara, 2008), 38.

9 Abuddin Nata, Akhlak Tasawuf dan Karakter Mulia, (Jakarta: RajaGrafindo Persada, 2014), 133.

10 Heri Gunawan, Tawadu Taat, Qanaah, dan Sabar, ( Bandung: Ma'rifat, 2009), 7.

e-ISSN: $2715-4572$

p-ISSN: 2716-1439 
Allah, namely a servant who believes and submits himself to him by embracing Islam."11

Behavioural character is innate from birth. ${ }^{12}$ For this group, the problem of character is the innate nature of humans themselves. Thus character will grow and develop by itself. On the other hand, there is also an opinion that says that character is the result of education, effort, cultivation, formation, training, guidance, coaching and hard and earnest struggle. Imam Al-Gazali in Abuddin Nata, for example, said that "if the character cannot accept change, then the function of will, advice and education is invalidated and there is no function of the prophet's hadith which says character education for you all."13

"Character is obtained through the process of internalizing what he knows, which takes time to form good character in human life."14 Given that the cultivation of character is a process, then this can be provided through formal, non-formal, or informal education that is carefully planned and designed. ${ }^{15}$

If it is seen in the community, family and school environment, there

Mulia, 133.

11 Nata, Akhlak Tasawuf dan Karakter

12 Handayani, Andi Muthia Sari, \&

Nurdin, Nurdin. (2021). Understanding Women's Psychological Well-Being in PostNatural Disaster Recovery. Medico Legal Update, 21(3), 151-161.

13 Ibid.

14 Zuriah, Pendidikan Moral dan Budi

Pekerti dalam Perpektif Perubahan, 38.

${ }^{15}$ Rusli, Rusli. (2014). Teaching Usul alFiqh: A Multicultural Education Model. AlTahrir: Jurnal Pemikiran Islam, 14(2), 447-464. are indeed many facts that character must be instilled through education. If not, then there is no point in Islamic religious education being taught to humankind, because in essence, religious education includes character education.

Abuddin nata says that:

Good character is the result of efforts to educate and train seriously the various spiritual potentials contained in humans. If the education and characterbuilding program are welldesigned, systematic, and carried out seriously, it will produce children or people with good morals. ${ }^{16}$

The function of educational institutions is as a place to instil character for children or adults. Then manners with other meanings can be interpreted

As a serious effort in the context of forming children, by using educational and coaching facilities that are well programmed and carried out seriously and consistently, the cultivation of character is carried out on the basis of the assumption that character is the result of coaching efforts, not happening by itself. ${ }^{17}$

\subsection{The Process of Cultivating Character}

According to Imam Al-Ghazali "Akhlaq education is the process of fostering the character of children so that

${ }^{16}$ Nata, Ahklak Tasawuf, 158.
17 Ibid. e-ISSN: $2715-4572$ p-ISSN: 2716-1439 
they become noble character (akhlaqul karimah)"18.

In this case, the role of educational institutions is very important in character education. Imam Al-Ghazali also said:

How to educate children's morals can be done with taqdim al-takhalai an alakhlaq al-mazmumah suma altahalli bi al-akhlaq al-maheasy, namely in bringing moral teachings or al-akhlaq al-maheasy is by takhalli (emptying or leaving) al- akhlaq almazmumah (deplorable morals), then tahalli (fill or implement) alakhlaq al-maheasy (commendable morals) $)^{19}$

Imam Al Ghazali's opinion is that the way to educate children's character is to fill our lives or carry out good deeds and discard or not do bad or despicable deeds so that if we get used to doing good things, over time, it will be embedded in ourselves. Someone or a child of good character and vice versa.

Imam Al Ghazali also advocated the story or saga method and the story of exemplary. Children also need to be accustomed to doing something good. With the story method or example, children will take lessons or good deeds so that children can imitate, practice and carry out in everyday life.

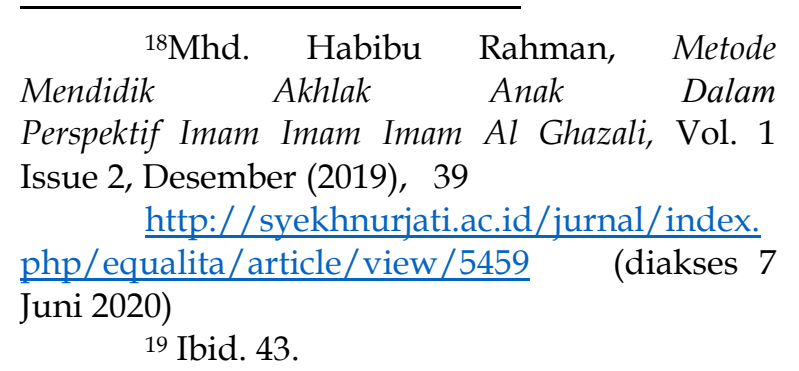

The way of habituation is done gradually. This includes changing negative habits into positive habits or behaviours. In an effort to create good/positive habits, this can be done in two ways, including through the process of guidance and training and by studying God's rules that exist in the universe, which are very regular in shape. Good habituation is very important for the formation of the character of a child or student and will also continue to affect the child until his old age. Instilling habits in children is sometimes difficult and takes a long time. However, everything that has become a habit will also be difficult to change. Therefore, it is better to keep the children or students in order to have good habits than to have bad habits. ${ }^{20}$

\subsection{Modeling}

By using the modelling process, namely the assimilation process or the process of imitation, the process of imitating children to other people who are their idols or people they respect. Modelling usually starts with admiration. The child is amazed by the intelligence of others, then he imitates it, for example, to the teacher who thinks that they can do everything the person cannot do. Gradually the feeling of admiration will affect his emotions, and slowly the child will imitate the behaviour of his idol. ${ }^{21}$

The process of inculcating a child's character in an object through the modelling process was initially carried

\section{Ibid. 46.}

21 Sanjaya, Srategi Pembelajaran Berorientasi Standar Proses Pendidikan, 276-277.

e-ISSN: 2715-4572

p-ISSN: 2716-1439 
out by imitation, but children need to be given an understanding of why it was done. For example, the teacher needs to explain why we have to be careful with plants or why we have to dress clean. This is necessary so that certain attitudes that arise are truly based on a belief in truth as a value system. ${ }^{22}$

According to Syaepul Manan, if school principals, teachers, and other employees exemplify noble character, students will imitate this behaviour. Over time, noble character will be instilled in students. In the end, these students will have good character. Noble so that it can be useful for oneself, others, religion and the nation. All of this has been proven by the results of research conducted in previous studies.

\section{Methodology}

This study uses a qualitative approach with the object of research is a government disabled school in Palu. In this study, the researchers took one of the government disabled school to be the case of the study. The case of this study was a state disabled in Palu city. Data were gathered through direct field observation, in-depth interviews which involve teachers and the school principla. We also analyzed written material 23 , such as the school teaching activities, to understand how the character building strategies were

\footnotetext{
22 Ibid.

23.. Nurdin, Nurdin. (2021). Employing
} Online and Offline Qualitative Interpretive Case Studies in Understanding E-Procurement Effectiveness. International Journal of Quantitative and Qualitative Research Methods, 9(1), 23-41. integrated in the disabled school curriculum

We used a qualitative methods in this study wuth several considerations. First, the qualitative methods is helpful when dealing with multiple realities. Second, it can directly present the nature of the relationship between researchers and informants ${ }^{24}$. Third, this method is more sensitive and adaptable to the many sharpening of the common direction and the patterns of values encountered. ${ }^{25}$ While the data analysis is done using reduction and verification techniques with various data sources. ${ }^{26}$ The reduced data is then analyzed by claiming to the theoretical concepts used in this study.

\section{Result and Discussion}

4.1 Strategies for inculcating character in mentally handicapped students

This study discusses the teacher's strategy in inculcating character for developmentally disabled children in

${ }^{24}$. Nurdin, Nurdin. (2021a). A Collective Action In Indonesia Local E-Government Implementation Success. INTERNATIONAL JOURNAL OF SCIENTIFIC \& TECHNOLOGY RESEARCH, 10(2), 160-166.

${ }^{25}$ Nurdin, Nurdin. (2018). Institutional Arrangements in E-Government Implementation and Use: A Case Study From Indonesian Local Government. International Journal of Electronic Government Research (IJEGR), 14(2), 44-63. doi: 10.4018/ijegr.2018040104

26 Nurdin, Nurdin, \& Aratusa, Zana Chobita. (2020). Benchmarking level interactivity of Indonesia government university websites. TELKOMNIKA Telecommunication, Computing, Electronics and Control, 18(2), 853-859.

e-ISSN: 2715-4572

p-ISSN: 2716-1439 
the subjects of Islamic Religious Education (PAI) and character at the State Special School (SLB) 2 Palu. Education is very important and cannot be separated in life, and its nature must exist in life both in the life of individuals, families, or a nation. In education, teachers must have the right strategy to instil noble character, which is able to make students become human beings, so that they can be useful for themselves, others or for religion and the nation.

Based on observations and interviews, researchers obtained the results that the State Special School (SLB) has implemented a strategy of inculcating character for developmentally disabled children in Islamic Religious Education (PAI) and character education subjects. There are several strategies used by religious education teachers, Islam (PAI) and good manners both during normal times and during the COVID-19 pandemic, one of which is comparative learning strategies, individual strategies and effective learning strategies. However, a prominent strategy that is often used to instil character for developmentally disabled children is the effective learning strategy. This effective learning strategy is the inculcation of positive attitudes or values in students with mental retardation, in the affective learning strategy emphasizes values and values. Attitudes that can be measured, values that are related to good and bad while attitudes are polite and impolite, then the second strategy that stands out that is often used by Islamic Religious Education (PAI) teachers and character is to apply individual learning strategies, which in individual learning strategies emphasize the value and attitude of independence and responsibility. As applied by Islamic Religious Education (PAI) and character education teachers at the State 2 Palu Extraordinary School (SLB), the Islamic Religious Education (PAI) teacher and manners apply good lessons, as does the behaviour of children with intellectual disabilities who are childish. the child the mind power is slow and often forgets, as expressed by the teacher of Islamic Religious Education (PAI) and his character said that

Teaching developmentally disabled children in the classroom requires patience, because usually developmentally disabled children when we teach their lessons here and there, then we must apply the learning that is liked by developmentally disabled children and in learning developmentally disabled children should not be forced, if forced, they will not even want to learn. ${ }^{27}$

Through the learning carried out by Islamic Religious Education (PAI) and character education teachers that learning will go well because learning that is liked by developmentally disabled children will stimulate developmentally disabled children so that developmentally disabled children

27 Tjinoria, Guru Mata Pelajaran Pendidikan Agama Islam (PAI) dan budi pekerti Sekolah Luar Biasa (SLB) Negeri 2 Palu. wawancara. Rumah Guru Pendidikan Agama Islam (PAI) dan budi pekerti Kelurahan Petobo 23 April 2020. 
will have good character, learn comfortably not to hate each other and angry with each other in the learning process, so that it will be instilled in developmentally disabled children mutual respect between students and teachers and students with fellow students.

Other good manners that will be instilled when the teacher teaches with patience will be an imitation or modelling process. In the modelling process, a developmentally disabled child will imitate the patient attitude that the teacher exemplifies.

Based on what the researchers obtained, it is indeed tough to instil character in schools, especially in schools with special needs or special schools (SLB), especially during the COVID-19 pandemic. These words are as expressed by a teacher of Islamic Religious Education (PAI) and character at the State 2 Palu Extraordinary School (SLB), he revealed that "Educating character for developmentally disabled children in SLB is indeed difficult because developmentally disabled children are usually difficult to manage, because while teaching usually they go out here and there ". The principal further strengthened this opinion, and he argued that "it is not easy to educate mentally retarded children, usually what is conveyed now, tomorrow they usually forget to repeat what is said now." 28 It is so difficult to instil character for

28 Bapak Sukiman, Kepala Sekolah Luar Biasa (SLB) Negeri 2 Palu, wawancara. Ruang kepala Sekolah Luar Biasa (SLB) Negeri 2 Palu, Jalan Nambo lorong, I, No. I. Kelurahan Petobo, 15 Juni 2020. developmentally disabled children so that a teacher must have a certain strategy to teach character to developmentally disabled children at the State 2 Palu Special School (SLB).

Follow-up observations and interviews carried out by the author at the State Special School (SLB) 2 Palu, namely asking about the strategy of inculcating character for developmentally disabled children in the subjects of Islamic Religious Education (PAI) and character at the State Special School (SLB) 2 Palu. The author's results were that the State 2 Palu Special School (SLB) had implemented a strategy of inculcating character for developmentally disabled children in the subjects of Islamic Religious Education (PAI) and character. There were several strategies for inculcating character for developmentally disabled children.

The strategies that Islamic Religious Education usually applies (PAI) and character education teachers are because at the school, and there are two types of mentally retarded children, namely mild mental retardation and moderate mental retardation. Islamic religious teachers use effective learning strategies. The process of effective learning strategies has two techniques in learning, namely learning techniques using habituation and modelling learning techniques, the second strategy that is often used is individual learning strategies. As is usually done by Islamic Religious Education (PAI) and character education teachers at the State Special School (SLB) 2 Palu, he uses learning through coaching in the form of e-ISSN: $2715-4572$ p-ISSN: 2716-1439 
habituation, for example, admonition, advice, maintaining cleanliness, giving individual assignments and training. Exercises such as being trained in giving charity and practicing prayer.

The development of character through this habituation can be done on a scheduled or unscheduled manner, either inside or outside the classroom. Habituation at school is a tradition that is carried out every day because character values will never be engraved without good habits and repetition of learning. Habits that are carried out before learning are maintaining the cleanliness of the learning place, cleaning the schoolyard every time a student comes to the school. School before the morning apple, then there is guidance on reciting short verses of Quran in the field during morning apples and before studying.

Islamic religious education and character teachers use effective learning strategies. Islamic religious education teachers and characters in the teaching process emphasize values and attitudes in developmentally disabled children more because affective learning strategies do much learning related to values and attitudes to participants educate. Then in learning Islamic Religious Education (PAI), teachers and manners involve the environment, both the peer environment, school environment, home environment or the surrounding community environment. So the author can say that one of the factors that influence the character of developmentally disabled children can be influenced by the environment, even though the behaviour of developmentally disabled children has been present since birth.

The moral values in some of the opinions above are that developmentally disabled children will have an attitude of caring for the environment, caring about the Koran because they have cleaned the school environment and recited short verses of Qur'an. The developmentally disabled children will have an attitude of cooperation and mutual assistance between teachers. With students and students with fellow students because developmentally disabled children have both cleaned the schoolyard, then developmentally disabled children will have an attitude of helping each other, complementing each other and complementing each other because they have recited short Quran verses together because someone has memorized and some did not memorize the Quran verses. ${ }^{29}$

These habits are daily activities implemented by Islamic Religious Education (PAI) and character education teachers to instil character in developmentally disabled children at the State Special School (SLB). Several statements that have been described by the researcher, Islamic Religious Education (PAI) and character education teachers have implemented a strategy of inculcating character in the form of coaching through positive habits, namely getting used to cleaning the schoolyard every morning when they

${ }^{29}$ Rusli, Rusli. (2009). Gagasan Khaled Abu Fadl tentang "Islam Moderat" versus "Islam Puritan" (Perspektif Sosiologi Pengetahuan). Jurnal Ilmiah Ilmu Ushuluddin, 8(1), 99-123. 
arrive at school and reciting short short verses of Qur'an every morning. Morning apple, because cleaning is one of the noble behaviours in the subject of Islamic Religious Education (PAI) and character because by cleaning the environment over time there will be stimulation and awareness in developmentally disabled children, then love for the environment and subconsciously instilled in developmentally disabled children noble character. Moreover, it is done repeatedly or continuously, if good behaviour is done repeatedly, it will be embedded in a person to become a noble character because he is used to doing this in his life, Cleanliness is a reflection of faith, and a believer is certain that he already has a noble character.

Reciting short short verses of Qur'an is our love for the Qur'an and Allah SWT. What is more, it is often done continuously for someone, a person who loves the Qur'an and Allah means that person has good character. Good in his life because he has been pious in carrying out Allah's commands. Reading the Koran will also make a child more patient with something that happens to him. By regularly reciting the Al-Qur'an, a child will easily control his emotions so that he will become a patient person. So that developmentally disabled children will have noble character. This can be seen by the habits that are carried out every day. If the habits are good, then good manners and vice versa.

The development of the character of developmentally disabled children can be done by getting used to certain positive behaviours in everyday life. Habituation is the formation of relatively permanent and automatic attitudes and behaviour through a repeated learning process, either together or individually. This will also cause stimulation to developmentally disabled children so that it will be instilled in developmentally disabled children with good character.

Another benefit of reciting the Qur'an can affect a person's state of mind so that it makes sense of calm and pleasure in him. Moreover, it is said together so that a child who reads the Qur'an can reduce stress and anxiety. The pressure that is on a child, so that a child will not do bad things that can harm himself or others, even they will do good things.

Islamic Religious Education (PAI) and character education teachers at the State Special School (SLB) 2 Palu have implemented an affective learning strategy in which the affective learning strategy contains positive values, attitudes and there is learning through habituation and modeling techniques.

When teaching developmentally disabled children they should not be fathered in learning, so they must slowly instil character in them, as expressed by the Islamic Religious Education (PAI) teacher and his manners revealed that "teaching developmentally disabled children cannot be fathered, if he does not want to learn yet, he cannot be fathered, if they want to play let him play first." 30

30 Tjinoria, Guru Mata Pelajaran Pendidikan Agama Islam (PAI) dan budi pekerti Sekolah Luar Biasa (SLB) Negeri 2 Palu . wawancara. Rumah e-ISSN: 2715-4572 p-ISSN: 2716-1439 


\subsection{The process of inculcating character for mentally handicapped children}

The development of the character of developmentally disabled children can be done by getting used to certain positive behaviours in everyday life. Habituation is a process of forming attitudes and behaviours that are relatively permanent and automatic through a learning process that is repeated, either together or individually. It will also produce competence. The development of character through this habituation can be done in a scheduled or unscheduled manner either inside or outside the classroom.

Routine activities in the form of coaching or habituation of teachers and mentally retarded every morning, Islamic Religious Education (PAI) and character education teachers at the State 2 Palu Special School (SLB) and other teacher friends reprimanded the children at school when they were young. -New schoolchildren arrive at school, Islamic Religious Education (PAI) teachers and manners and other teacher friends guide developmentally disabled children and other children to clean the schoolyard before the morning ring start.

After the school environment is clean, it will start morning apple, during the morning apple the Islamic Religious Education (PAI) teacher and manners and other teacher friends familiarize developmentally disabled children and other children to recite short short verses

Guru Pendidikan Agama Islam (PAI) dan budi pekerti Kelurahan Petobo 23 April 2020. of Qur'an together, if the pronunciation is wrong, the teacher reprimands the participants taught and told to repeat it again while being guided slowly. As expressed by the teacher of Islamic Religious Education (PAI) and his manners, he said that:

How to instil character for developmentally disabled children by making a habit of cleaning the schoolyard together every morning, then morning apples, in the morning ring we also get used to reciting short short verses of Qur'an repeatedly, if there are students who say the wrong words, we have to recite the short verses of Qur'an again. ${ }^{31}$

During the COVID-19 pandemic, habituation learning carried out in schools was transferred and carried out at the homes of Islamic Religious Education (PAI) and character education teachers, although not the same as those in schools. As expressed by the teacher of Islamic Religious Education and his manners, he revealed that

"Instilling the character of developmentally disabled children when the current situation and conditions I usually teach children at my house, children come to the house accompanied by their parents, and I continue to use learning as $I$ do at school, such as cleaning before studying, the difference is that at school the children clean the yard and

31 Tjinoria, Guru Mata Pelajaran Pendidikan Agama Islam (PAI) dan budi pekerti Sekolah Luar Biasa (SLB) Negeri 2 Palu. wawancara. Rumah Guru Pendidikan Agama Islam (PAI) dan budi pekerti Kelurahan Petobo 23 April 2020.

e-ISSN: 2715-4572

p-ISSN: 2716-1439 
class, if at home like this clean the study area before studying, I tell them to recite a short verse of the Al-Qur'an, if they forget, I tell them to repeat it again" 32

The process of inculcating character in schools is different from the process of inculcating character during the COVID-19 pandemic when at school, the process of inculcating character can be scheduled. However, during the COVID-19 pandemic, the process of inculcating character in the homes of Islamic Religious Education (PAI) teachers and morals character or outside the network is usually called offline learning, the learning is uncertain because of the situation and conditions.

The morals embedded in developmentally disabled children from some of the opinions above are that developmentally disabled children will have an attitude of caring for the environment, caring about the Al-Qur'an because they have cleaned the school environment and recited short verses of Qur'an. Then developmentally disabled children will have an attitude of mutual cooperation and mutual assistance between teachers and students and students with fellow students because developmentally disabled children have both cleaned the schoolyard, then developmentally disabled children will

32 Tjinoria, Guru Mata Pelajaran Pendidikan Agama Islam (PAI) dan budi pekerti Sekolah Luar Biasa (SLB) Negeri 2 Palu. wawancara. Rumah Guru Pendidikan Agama Islam (PAI) dan budi pekerti Kelurahan Petobo 05 Agustus 2020. have an attitude of helping each other, complement each other and complement each other because they have to recite short surah together is caused by some who memorize and some do not memorize short surah.

Maintaining cleanliness and environmental sustainability in schools is one of the most important elements in creating a comfortable and safe school environment

conducive to influencing the personality and character development of developmentally disabled children. Students' habit of maintaining cleanliness and environmental sustainability reflects the realization of the cultivation of environmentally caring character in the State 2 Palu Special School (SLB).

On the other hand, Suminem revealed that "Children cleaning the schoolyard every morning, then have a morning call, and at the morning we get into the habit of reciting short verses of Qur'an to them." These routine activities are carried out so that developmentally disabled children and other children get used to applying them in daily life so that developmentally disabled children have a noble character because cleanliness is a reflection of the heart, if a child likes cleanliness and it is done regularly, it means that the child has a noble character because of love for the environment.

Reciting short surah is our love for the Qur'an and for Allah. What is more, it is often done continuously for someone, a person who loves the Qur'an and Allah means that person has good character. Good in life because he has

e-ISSN: 2715-4572

p-ISSN: 2716-1439 
been pious in carrying out Allah's commands. This can be seen by the habits that are carried out every day. If the habits are good, then good manners. Reciting the Qur'an can affect a person's state of mind so that it makes sense of calm and pleasure in them, especially when it is said together.

That way, a child who reads the Qur'an can reduce the stress and pressure that exists on a child so that a child will not do bad things that can harm himself or others. They will even do good things.

Reading the Qur'an will also make a child more patient with something that happens to him. By regularly reciting the Qur'an, a child will easily control his emotions so that he will become a patient person. So that developmentally disabled children will have noble character.

After the routine every morning cleaning the schoolyard and reciting short surah in the morning call, the next activity is entering the classroom. In the class usually, the Islamic Religious Education (PAI) teacher and manners repeat again reciting short surah, but before repeating reciting short surah, the Islamic Religious Education (PAI) teacher and character look at the situation and condition of the students before carrying out activities. As expressed by the Islamic Religious Education (PAI) teacher and character, he argues that "after reciting short verses of Qur'an before entering class and after entering class, sometimes it is repeated together and after being together then one by one sometimes it does not. because of the condition of the students." 33

During the pandemic conditions, reciting short verses of Qur'an was also carried out, namely by learning outside the network or offline as stated by the Islamic Religious Education teacher, he argued that "reciting short surah together, after being together then one by one, if the child mispronounced short verses of Qur'an, I told them to repeat them again until they were fluent in pronouncing them." 34

The process of inculcating character in schools is clearly different from the process of inculcating character during the COVID-19 pandemic. At school, the process of inculcating character can be scheduled, but during the COVID-19 pandemic, the process of inculcating character at home or outside the network is usually called offline learning. The learning is not determined because of the situation and conditions.

\section{Conclusion}

The teacher's strategy in inculcating character for developmentally disabled children in

33 Tjinoria, Guru Mata Pelajaran Pendidikan Agama Islam (PAI) dan budi pekerti Sekolah Luar Biasa (SLB) Negeri 2 Palu. wawancara. Rumah Guru Pendidikan Agama Islam (PAI) dan budi pekerti Kelurahan Petobo 23 April 2020.

34 Tjinoria, Guru Mata Pelajaran Pendidikan Agama Islam (PAI) dan budi pekerti Sekolah Luar Biasa (SLB) Negeri 2 Palu. wawancara. Rumah Guru Pendidikan Agama Islam (PAI) dan budi pekerti Kelurahan Petobo 05 Agustus 2020.

e-ISSN: $2715-4572$

p-ISSN: 2716-1439 
Islamic Religious Education (PAI) and character at the State 2 Palu Special School (SLB) during normal times or during the COVID-19 pandemic using offline learning strategies effective learning through habituation and modelling techniques. The other strategies for mild developmentally disabled children and for a moderate mental disabled individual or individual strategies.

The process of inculcating character for developmentally disabled children in the subjects of Islamic Religious Education (PAI) and character at the State Special School (SLB) 2 Palu, namely Islamic Religious Education (PAI) teachers and character applying habits that contain values and attitudes that good habits, such as getting used to maintaining cleanliness, reciting short surah, practicing prayer, getting used to giving charity, telling exemplary stories inside and outside the classroom, teachers setting good examples for developmentally disabled children, teachers reprimanding and giving good advice when children mentally retarded do wrong. The next process is that the Islamic Religious Education (PAI) teacher and manners assign tasks one by one to children with mild and moderate mental retardation.

\section{REFERENCES}

Adisusilo Sutarjon. J.R.. Pembelajaran NIlai Karakter. Cet.1; Jakarta: PT RajaGranfindo Persada. 2012.
Agustinova Eko Danu. Memahami Metode Penelitian Kualitatif. 'Yokyakarta: Calpulis. 2015'.

Ahmadi Rulan. Metode Penelitian Kualitatif. Yokyakarta; ARRUZZ MEDIA. 2016.

Amrih Agung Gunawan dkk. Bimbingan Keterampilan Hidup Personal Bagi Anak Tuna Grahita Ringan Di SLB Kota Bandung. Vol. 4 No. 1 'Januari 2017'. 59

http:/ / ejournal.utp.ac.id/index. php/JMSG/article/view/484

'Diakses 14 Desember 2019'.

Anitah Sri. Strategi Pembelajaran di SD. Tangerang Selatan : UNIVERSITAS TERBUKA. 2017.

Askar, Askar, Adawiyah, Adawiyah, \& Nurdin, Nurdin. (2021). Understanding Students' Psychological Distress Complaints through Online Academic Advising Support. Medico Legal Update, 21(3), 162167.

Aqila Smart. Anak Cacat Bukan Kiamat Metode Pembelajaran. dan Terapi untuk Anak Berkebutuhan Khusus. Cet.4 ; jokjakarta. KATAHATI AR-RUZZ MEDIA. 2016.

Baso Ahmad. Islam Nusantara. Cet.1. Jakarta: Pusta Afid. 2015.

Bungin Burhan. Metode Penelitian Kualitatif. Cet. 8; Jakarta: PT Rajagranfindo Persada. 2011.

Chakim Lukman. Akidah Akhlak. Cet. 1; Jakarta: Direktorat Pendidikan Madrasah Direktoran Jedral Pendidikan Islam Kementrian e-ISSN: 2715-4572 p-ISSN: 2716-1439 
Agama Republik Indonesia. 2015.

Darmansyah. Strategi Pembelajaran Menyenangkan Dengan Humor. 'Cet.3; Jakarta: PT Bumi Aksara. 2012 '.

Dayu Pratyahara. Mendidik Anak ADHD 'Attention Deficit Hyperactivity Disorder' Hal-hal yang Tidak Bisa Dilakukan Obat. Jokjakarta: Kradenan RT. 10 RW. 69 Maguwoharjo. 2014.

Darwis Muhammad Dasopang. Balajar dan Pembelajaran. Vol. 03 No. 2 Desember ' 2017'. 337. http://jurnal.iainpadangsidimpuan.ac.id/index. $\mathrm{php} / \mathrm{F} /$ article/view/945

'diakses 27 Desember 2019'

Departemen Agama Republik Indonesia. Al-Qur'an dan Terjemahnya. Surabaya: CV. Karya Utama. 2005. Eliyanto. Pendidikan Nilai dalam Budi Pekerti. Vol. 2 No. 1. '2018'. 124. http://www.ejournal.iainukebumen.ac.id/index.php/cka/ article/view/41. 'diakses 1 Januari 2020'.

Erika Widya Rohmatrismaysi. Harmanto. Strategi Guru Dalam Mengembangkan Karakter Percaya Diri Dan Tangoung Jawab Siswa Di SLB Cendekia Kabuh Jombang. Volume 05 Nomor 01 '2017'. 166 - 180. https://jurnalmahasiswa.unesa. ac.id/index.php/jurnal-

pendidikan-

kewarganegaraa/article/view/

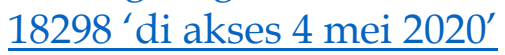

Erawati Imas. dkk. Menumbuhkan Karakter Anak Tunagrahita Melalui Pemberian Reward. Vol. 1 No. 4 '2019'. 715-723. http://jonedu.org/index.php/j oe/article/view/239 'di akses 26 Januari 2020'.

Fadjryana Siti Fitroh dkk. Dongeng Sebagai Media Penanaman Karakter Pada Anak Usia Dini. Vol. 2. No. 2 '2015'. $97 . \quad$ https://ecoentrepreneur.trunojoyo.ac.id/p gpaudtrunojoyo/article/view/ 2606 'diakses 11 Januari 2020'

Fadlilah Siti. Strategi Pembelajaran PAI Bagi Peserta Didik Tunagrahita di SD Suryo Bimo Kresno Semarang. 'Semarang: UIN WALI SONGO. 2017'. http:/ / eprints.walisongo.ac.id/ 8379/ 'di akses 26 Januari $2020^{\prime}$

Gunawan Heri. Tawadhu. Taat. Qana'ah dan Saabar. Cet.1; Bandung: Ma'krifat. 2009.

Hafidhuddin Didin. Pendidikan Karakter Berbasis Al-Qur'an. Cet.1 Jakarta: PT Raja Grafindo Persada. 2012.

Hakib Iwan. Implementasi Teori Belajar Robert Gagne Dalam Pembelajaran Konsep Matematika '2016'. 20.

https://d1wqtxts1xzle7.cloudfr ont.net/53042280/IMPLEMEN TASI_TEORI_BELAJAR_ROBE RT_GAGNE_DALAM_PEMBE LAJARAN_KONSEP_MATEM ATIKA. 'di akses 13 Januari $2020^{\prime}$

Handayani, Andi Muthia Sari, \& Nurdin, Nurdin. (2021). e-ISSN: 2715-4572 p-ISSN: 2716-1439 
Understanding Women's

Psychological Well-Being in Post-

Natural Disaster Recovery.

Medico Legal Update, 21(3), 151161.

Hendracipta Nana. Perbedaan Hasil Belajar Siswa Antara Yang Menggunakan Srategi Inkuiri Dengan Strategi Ekspositori. Volume 3 Nomer 1 '2017' 35. http://jurnal.untirta.ac.id/inde x.php/jpsd/article/download/ $1137 / 2689$ 'di akses 11 Januari $2020^{\prime}$

Hidayat Nur. Akhlak Tasawuf. Cet.1; Yokyakarta: Ombak. 2013.

Ibrahim T. Membangun Akidah dan Akhlak. Cet. 1; PT Tiga Serangkai Pustaka Mandiri. 2009.

Indria Venny Ekowati dkk. Ajaran Budi Pekerti dalam Iluminasi Naskah Babad Kartasura Sukawati. Vol. 8. No. 1. '2018' 135.

http://journal.perpusnas.go.id Lindex.php/manuskripta/articl e/view/104'diakses 17 Desember 2019'.

Janet Herly Lesilolo, Penerapan Teori Belajar Sosial Albert Bandura Dalam Proses Belajar Mengajar Di Sekolah, Vol. 4 No. 2, (2018), 189-190, http://ejournal.iaknambon.ac.id/index. php/KNS/article/view/67 (diakses 12 Agustus 2020)

Siti Khosiah Rochmah, Rika Sa'diyah, Strategi Pembelajaran PAI Pada Peserta Didik Tunagrahita Sekolah Dasar Kelas Awal Di Sekolah Dasar Luar Biasa (SDLB) Pembina
Tingkat I Cilandak Lebak-Bulus Jakarta Selatan, vol. 2, no 01, ( 2017 ), 36,

http://journal.iaincurup.ac.id/i ndex.php/belajea/article/view $\angle 270$ (diakses 6 Agustus 2020)

Lisnawaty Sri Dewi. Keunggulan Metode Story Telling Dalam Membentuk Kualitas Karakter Dan Moral Mahasiswa. Vol. 1. No. 1 '2020'. 39-47.

http://moderasi.org/index.php /moderasi/article/view/8 'di akses 11 Januari 2020'

Maiwanly Yagung dkk. Peran Didikan Orang Tua dan Lingkungan Sosial Terhadap Pembentukan Kepribadian Anak Tinjauan Aliran Konvergensi. 2. https://osf.io/preprints/3x45v L'diakses 14 Januari 2020'

Manan Syaepul. Pembinaan Akhlak Mulia Melalui Keteladanan Dan Pembiasaan. Vol. 15 No. 1. '2017'.

http://jurnal.upi.edu/file/05_P EMBINAAN_AKHLAK_MULI

A_Manan1.pdf 'di akses 1 februari 2020'.

Masjid. Abdul. Andayani. Dian. Pendidikan Karakter Perspektif Islam. Cet. 2; Bandung: PT Remaja Rosdakarya. 2012.

Milka Kontribusi Teori Belajar Gagne Dalam Meningkatkan Kompetensi Pedagogik Pendidik. Vol. 3 No. 2. '2014'. 601. http://journals.ukitoraja.ac.id/i ndex.php/jkip/article/downloa $\underline{\mathrm{d} / 180 / 153}$ 'di akses 13 Januari $2020^{\prime}$. 
M. Aphroditta. Panduan Lengkap Orang tua dan Guru untuk Anak Disgrafia 'Kesulitan Menulis'. Cet.2 ;Jokjakarta: JAVALITERA Kradenan RT. 10 RW. 69 Maguwuharjo. 2013'. 45-46.

Muhammad Mawardi Amin. Membangun Pribadi Berbudi Pekerti. 'Yokyakarta: CALPULIS. 2016'.

Mustafa Hasan. Perilaku Manusia Dalam Perspektif Psikologi Sosial. Vol. 7. No. 2 (2011). 146. https://journal.unpar.ac.id/ind ex.php/JurnalAdministrasiBisni s/article/download/410/394 (diakses 16 Januari 2020)

Mularsih Heni. Pembelajaran Individual Dengan Menggunakan Modul. Volume 9 Nomer 1 '2007'. 2 http://repository.untar.ac.id/7 551/'diakses 11 Januari 2020

Munir Abdullah. Pendidikan Karakter Membangun Karakter Anak Sejak Dari Rumah. 'Yokyakarta : PT Pustaka Instan Madani. Anggota Ikapi. 2010'.

Nata Abuddin. Perpektif Islam tentang strategi pembelajaran. Cet.1; Jakarta: Kencana Prenadamedia Group. 2009.

Ahklak Tasawuf. Cet.9; Jakarta: RajaGrafindo Persada. 2010.

Narbuko Cholid dan Abu Achmadi. Metode Penelitian. 'Cet. 15; Jakarta: Sinar Grafika Offset. 2016'.

Nur Fitriani Alifah, Pengembangan Strategi Afektif, Vol. V, No. 1, '2019', $\underline{\text { ndex.php/Tadrib/article/view }}$ $\angle 2587$

Nurdin, Nurdin. (2021). A Collective Action In Indonesia Local EGovernment Implementation Success. INTERNATIONAL JOURNAL OF SCIENTIFIC $\mathcal{E}$ TECHNOLOGY RESEARCH, 10(2), 160-166.

Nurdin, Nurdin. (2018). Institutional Arrangements in E-Government Implementation and Use: A Case Study From Indonesian Local Government. International Journal of Electronic Government Research (IJEGR), 14(2), 44-63. doi: 10.4018/ijegr.2018040104

Nurdin, Nurdin. (2021). Employing Online and Offline Qualitative Interpretive Case Studies in Understanding E-Procurement Effectiveness. International Journal of Quantitative and Qualitative Research Methods, 9(1), 23-41.

Nurdin, Nurdin, \& Aratusa, Zana Chobita. (2020). Benchmarking level interactivity of Indonesia government university websites. TELKOMNIKA Telecommunication, Computing, Electronics and Control, 18(2), 853-859.

Prastowo Andi. Metode Penelitian Kualitatif Dalam Perpektif Rancangan Penelitian. Cet. 3;Jokjakarta: AR-RUZZ MEDIA. 2016.

Pusat Bahasa Departemen Pendidikan Nasional. Kamus Besar Bahasa Indonesia. ' Jakarta : BALAI PUSTAKA. 2005'. 
Rahman Abdur. Madrasah dan Pendidikan Anak Bangsa. Cet.1; Jakarta: PT Raja Granfindo Persada. 2004.

Rahman Mhd. Habibu. Metode Mendidik Akhlak Anak Dalam Perspektif Imam Al-Ghazali. Vol. 1 Issue 2. Desember '2019'. 44 http://syekhnurjati.ac.id/jurnal Lindex.php/equalita/article/vi ew /5459 'di akses 7 Juni 2020'

Rochyadi E.. Karakteristik dan Pendidikan Anak

Tunagrahita.' 2012' 3.

http://file.upi.edu/Direktori/F IP/JUR._PEND._LUAR_BIASA /195608181985031ENDANG_R OCHYADI/MODUL/PGSD440 9-M6-LPK.pdf. 'diakses 12 Januari 2020'

Rohman Abdul. Pembiasaan Sebagai Basis Penanaman Nilai-Nilai Akhlak Remaja. Vol. 6 No. 1. '2012' 165. http:/ /journal.walisongo.ac.id/ index.php/Nadwa/article/vie w/462 'di akses 1 februari 2020'.

Ruslan. Penanaman Nilai-nilai Moral Pada Siswa Di SD Negeri Lampeuneurut. Vol. 1. No. 1. '2016'. 70. http://www.jim.unsyiah.ac.id/ pgsd/article/view/431 . 'di akses 11 Januari 2020'.

Rusli, Rusli. (2020). The Role of Family in Preventing Social Conflict in Society From Islamic Perspectives. HUNAFA: Jurnal Studia Islamika, 17(1), 108-122.

Rusli, Rusli. (2014). Teaching Usul alFiqh: A Multicultural Education Model. Al-Tahrir: Jurnal Pemikiran Islam, 14(2), 447-464.
Rusli, Rusli. (2009). Gagasan Khaled Abu Fadl tentang "Islam Moderat" versus "Islam Puritan" (Perspektif Sosiologi Pengetahuan). Jurnal Ilmiah Ilmu Ushuluddin, 8(1), 99-123.

Rustina. Keluarga dalam Kajian Sosiologi. Vol. 6 No. 2 '2014'. 302. https://media.neliti.com/medi a/publications/114514-IDkeluarga-dalam-kajiansosiologi.pdf 'diakses 2 februari $2020^{\prime}$

Sabrin Ahmad . strategi belajar mengajar dan micro teaching 'Ciputat: PT CIPUTAT PRESS 2007’. 30.

Sanjaya Wina. Strategi Pembelajaran. Cet.10; Jakarta: Kencana Prenadamedia Group. 2013.

Satria Ade. Meningkatkan Kemampuan Mengenal Lambang Bilangan 1 Sampai 5 Melalui Media Flash Card Bagi Siswa Tunagrahita Sedang . Volume 1 Nomer 3 '2013'. 16 http:/ / ejournal.unp.ac.id/index .php/jupekhu/article/view/11 24 'diakses 12 Januari 2020'

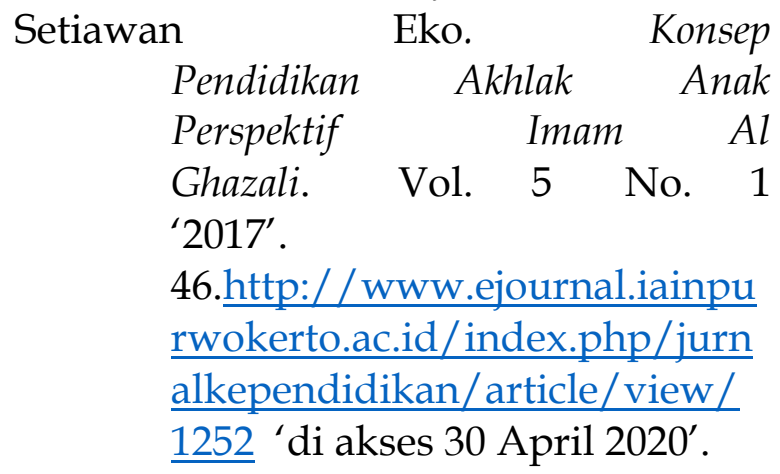

Sjarkawi. Pembentukan Kepribadian Anak. 'Jakarta: PT Bumi Aksara. 2015'. Somantri Sutjihati i. Psikologi Anak Luar biasa. 'Bandung: Refika Aditama. 2006'.103

e-ISSN: 2715-4572

p-ISSN: 2716-1439 
Soendari Tjutju \& Muhdar Mahmud. Strategi Pembelajaran Kooperatif dalam Meningkatkan Prestasi Belajar Berhitung Anak Tunagrahita Ringan Di Sekolah Luar Biasa. 2 http:// file.upi.edu/Direktori/F IP/JUR._PEND._LUAR_BIASA $\angle 195602141980032-$

TJUTJU_SOENDARI/Artikel/A rtikel_SPK.pdf 'di akses 11 Januari 2020'

Sugiono. Metode Penelitian Pendidikan. Cet.20; Bandumg: Alfabeta. 2014.

Suswandari Meidawati. Selayang Pandang Implikasi Aliran Pendidikan Klasik. Vol. 1 No. $1 . \quad 2017$ '. 34. http://journal.univetbantara.ac. id/index.php/komdik/article/ view/14 'di akses 1 februari $2020^{\prime}$.

Suprihatiningrum Jamil. Strategi Pembelajaran Teori dan Aplikasi. Jokjakarta: AR-RUZZ MEDIA. 2016.

Trianto. Pengantar Penelitian Pendidikan Bagi Pengembangan Profesi pendidikan dan Tenaga Kependidikan. Cet.1; Jakarta: Kencana Prenada Media Group. 2010.

Widiyati Wiwik. Belajar Dan Pembelajaranperspektif Teori Kognitivisme (2014). 177-178. https://jurnal.iainambon.ac.id/ index.php/BS/article/viewFile /521/404 (di akses 15 Januari 2020)

Zuriah. Nurul. Pendidikan Moral dan Budi Pekerti dalam Perpektif Perubahan.
Cet.2; Jakarta: PT. Bumi Aksara. 2008.

Zurqoni. Menakar Ahklak Siswa. Cet.2; Jokjakarta: Ar-Ruzz Media. 2013. 